\title{
HEINÄ-KAURA DIEETTI RATSUHEVOSTEN ENERGIAN, SULAVAN RAAKAVALKUAISEN SEKÄ KIVENNÄIS- JA HIVENAINEIDEN LÄHTEENÄ
}

\author{
Vappu Kossila, Erkki Virtanen ja Johanna Maukonen \\ Helsingin yliopiston kotieläintieteen laitos
}

Saapunut 12. 9. 1972

\begin{abstract}
HAY-OAT DIET AS A SOURCE OF ENERGY, DIGESTIBLE CRUDE PROTEIN, MINERALS AND TRACE ELEMENTS FOR SADDLE HORSES

\author{
VAPpu Kossila, Erkki Virtanen and Johanna Maukonen \\ Department of Animal Husbandry, University of Helsinki
}

\begin{abstract}
Feed intake of 24 saddle horses was measured in May (I) and that of 22 horses in September (II). Mean live weight of the horses was about $550 \mathrm{~kg}$. Diet contained timothy-dominating hay in I but timothy-clover hay in II. During I and II mean intake of hay was 6.4 and $7.1 \mathrm{~kg}$, that of oats 3.8 and $4.3 \mathrm{~kg}$. Mean energy intake in feed units (FU) from hay was 3.49 and $3.20 \mathrm{FU} /$ day and mean intake of digestible crude protein (DCP) 320 and $330 \mathrm{~g} /$ day respectively. Mean energy intake from oats was 3.41 and 3.27 FU/day and DCP-intake 324 and 372 g/day. Compared to generally accepted recommendations, the daily DCP-intake/horse was sufficient. Dry matter consumption was about $10 \mathrm{~kg}$ on an average per horse. Larger horses consumed more than smaller ones.

22 horses were regularly used for riding. For these the daily energy expenditure for, maintenance was calculated according to the recommendations of LARsson et al. (1951). During I and II the amount of energy required for the maintenance of the horses was 4.77 FU and the energy expenditure per hour of work was $1.38 \mathrm{FU}$ on an average. Mares required less energy per hour of work $(0.99 \mathrm{FU})$ than geldings and horses of the riding school required less energy ( $1.01 \mathrm{FU})$ than privately owned horses (2.39 FU).

When the energy expenditure per hour of work was calculated according to HrNTz et al. (1971), it was found that mares used 11.6 and $9.7 \mathrm{kcal} \mathrm{DE} / \mathrm{hr} / \mathrm{kg}$ during I and II; geldings used 12.9 and $12.7 \mathrm{kcal} \mathrm{DE} / \mathrm{hr} / \mathrm{kg}$ respectively. Ordinary riding horses required less energy (I 10.0 and II $8.7 \mathrm{kcal} \mathrm{DE} / \mathrm{hr} / \mathrm{kg}$ ) than privately owned, more intensively trained horses (I 19.2 and II $20.5 \mathrm{kcal} \mathrm{DE} / \mathrm{hr} / \mathrm{kg}$ ).

Mean daily intakes of minerals and trace elements per horse during I and II were: Ca 23.6 and $34.4 \mathrm{~g}, \mathrm{P} 23.8$ and $25.0 \mathrm{~g} ; \mathrm{Mg} 11.9$ and $13.0 \mathrm{~g}, \mathrm{~K} .99 .5$ and $113.0 \mathrm{~g}, \mathrm{Na} 9.8$ and $22.5 \mathrm{~g}, \mathrm{Fe} 695$ and $1592 \mathrm{mg}, \mathrm{Cu} 357$ and $201 \mathrm{mg}, \mathrm{Zn} 492$ and $348 \mathrm{mg}, \mathrm{Mn} 355$ and $388 \mathrm{mg}$; the $\mathrm{Ca} / \mathrm{P}$ of the diets were 0.99 and 1.39 respectively. The portions of minerals and trace elements obtained from hay during I and II were: Ca 71 and $90 \%$, P 44 and $47 \%, \mathrm{Mg} 62$ and $63 \%, \mathrm{~K} 85$ and $94 \%, \mathrm{Na} 81$ and $88 \%, \mathrm{Fe} 58$ and $52 \%$, Cu 66 and $72 \%$, Zn 55 and $54 \%$, Mn 49 and $50 \%$.

Compared to the generally accepted recommendations, the intakes of minerals and trace elements were sufficient or abundant except the intakes of $\mathrm{Ca}, \mathrm{Na}$ and $\mathrm{Fe}$ during $\mathrm{I}$.
\end{abstract}

Lämminverihevosten käyttö urheilutarkoituksiin on maassamme viime vuosina lisääntynyt huomattavasti. Koska lämminverihevosten menestyksellinen hoito ja käyttö 
riippuu oleellisesti hevosen ruokinnasta ja koska tietomme tästä ovat puutteelliset, on kotieläintieteen laitoksella katsottu aiheelliseksi suorittaa rehunkulutus- ja ravinnonsaantitutkimuksia lämminverihevosilla oloissamme. Tutkimuksessa pyrittiin selvittämään missä määrin heinä-kauravaltaisella ruokinnalla pidetyt ratsuhevoset kuluttavat rehua ja missä määrin heinä-kauraruokinta pystyy tyydyttämään ratsuhevosten sulavan raakavalkuaisen sekä kivennäis- ja hivenaineiden tarpeen.

\section{Aineisto ja menetelmät}

K o e-e lä i m e t. Rehunkulutustutkimukset suoritettiin Helsingissä Tuomarinkylän Ratsastuskoulussa 24 ratsulla toukokuussa ja 22 ratsulla syyskuussa 1971. Ratsujen säkäkorkeus vaihteli $124-173 \mathrm{~cm}: \mathrm{n}$ ja elopaino $325-662 \mathrm{~kg}$ :n välillä. Hevosten eräät kokoa karakterisoivat mitat ym. tietoja on annettu Taulukossa 2. Yhtä täysiveritammaa, yhtä ponia ja yhtä kevytrakenteista Suomen hevosta lukuunottamatta koeeläimet olivat puoliveriratsuja.

$\mathrm{Ruokinta}$. Varsinainen rehunkulutustutkimusperiodi kesti toukokuussa (I) 10 vrk ja syyskuussa (II) 19 vrk. Hevoset madotettiin ennen II-koetta Loisolilla. Hevosten ruokinta perustui pääasiallisesti heiniin ja kauroihin, jotka oli kasvatettu Helsingin alueella. Toukokuussa syötetty heinä oli timoteivaltaista, syyskuussa heinissä oli apilaa joukossa. Kaurat annettiin kokojyvinä. Ruokintaohjelma oli seuraava:

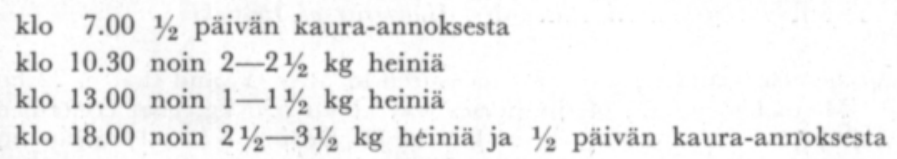

Syömättä jääneet heinäntähteet punnittiin ennen uuden heinäannoksen antamista. Heinäannokset pyrittiin järjestämään sellaisiksi, että tähteitä jäi mahdollisimman vähän. Kaura-annoksista ei tähteitä jäänyt. Juomavettä hevoset saivat halunsa mukaan automaattisesta juomakupista. Muutamat yksityishevoset saivat kauran ja heinien ohella aina 1 rehuyksikköön saakka päivässä lisärehua (Taulukko 2).

$\mathrm{R}$ eh uan a lyysit. Heinien ja kaurojen koostumus ja ravintoarvo selvitettiin rehuanalyysein (Taulukko 1). Raakavalkuainen, kuiva-aine (ka), kuitu, tuhka ja ryarvo määritettiin rutiinimenetelmillä. Lisärehujen ravintoarvo saatiin vakuutustodistukista. Heinien ja kaurojen sisältämät kationit $(\mathrm{Ca}=$ kalsium, $\mathrm{Mg}=$ magnesium, $\mathrm{K}=$ kalium, $\mathrm{Na}=$ natrium, $\mathrm{Fe}=$ rauta, $\mathrm{Cu}=$ kupari, $\mathrm{Zn}=$ sinkki, $\mathrm{Mn}=$ mangaani) määritettiin kuivapolttomenetelmällä ja Varian Techtron AA-1000 atomiabsorptiospektrofotometrillä. Fosfori (P) määritettiin TAusskyn ja ScHoRrin (1953) menetelmällä.

Hevosten kä y t tö työhön. Tuomarinkylän Ratsastuskoulun hevosia käytettiin ratsastustunneilla iltapäivisin klo 13.00 - 20.00 välisenä aikana ja niiden työtunneista pidettiin kirjaa. Sunnuntaisin niillä oli vapaapäivä. Yksityishevosia, joita tutkimuksessa oli mukana 8 , käytettiin ratsastukseen noin yksi tunti päivässä. Hevosten työtunnit keskim. päivässä tutkimusajanjaksoina on annettu Taulukossa 2. Toukokuussa kahta ratsua (Almi ja Katja) ja syyskuussa yhtä ratsua (Puma) ei jalkavian takia käytetty koko tutkimuksen aikana ratsastamiseen (seisoivat). 
Taulukko 1. Toukokuussa (I) ja syyskuussa (II) suoritetuissa rehunkulutustutkimuksissa käytettyjen heinien ja kaurojen koostumus.

Table 1. Composition of the hay and oats used during the feed intake studies in May (I) and September (II).

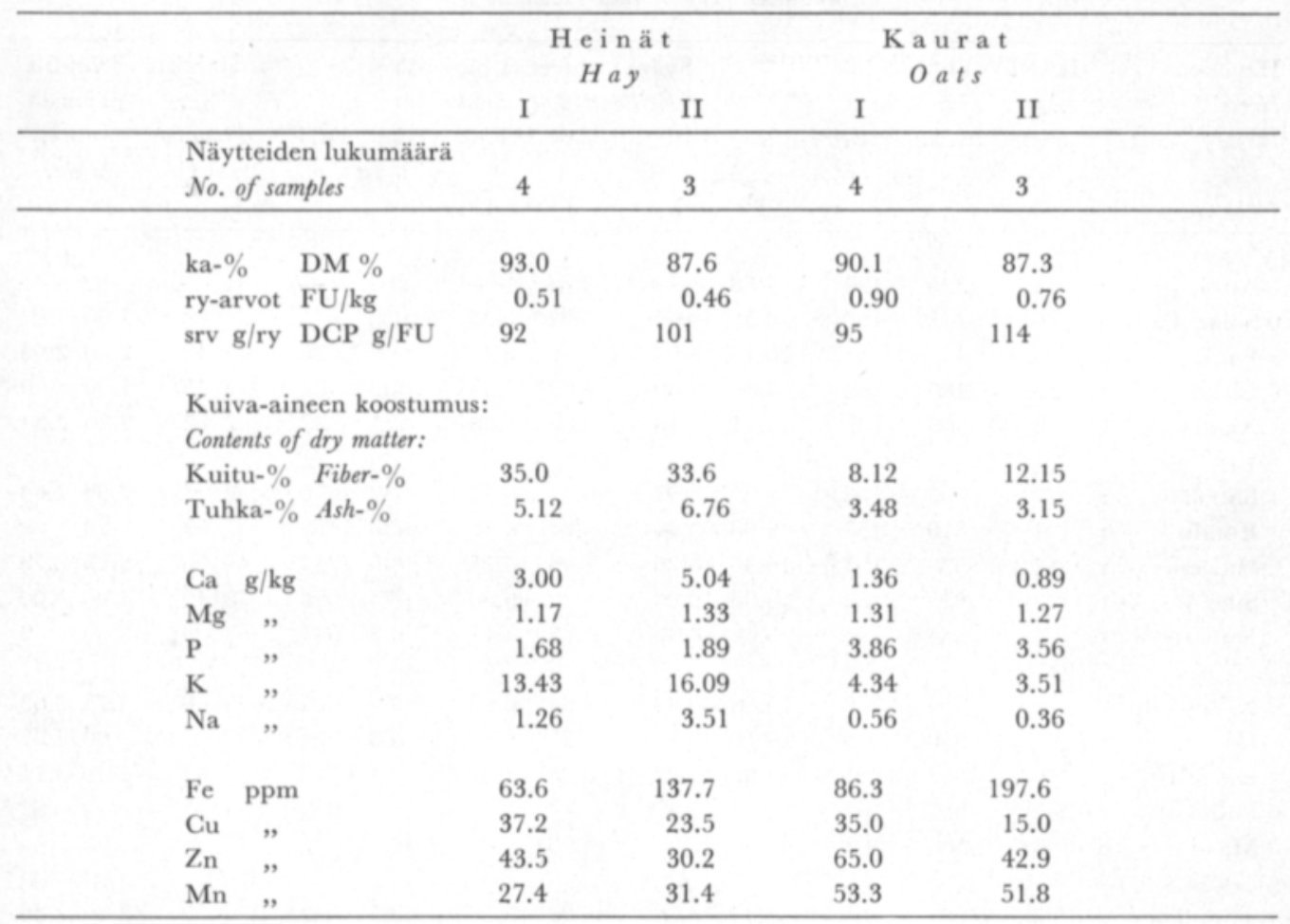

$D M=$ dry matter; $F U=$ feed unit $=0.7$ starch unit; $D C P=$ digestible crude protein

\section{Tulokset}

R e h u t. Tutkimuksessa käytetyt heinät ja kaurat olivat rehuanalyyseissä saatujen tulosten perusteella laadullisesti tyydyttäviä. Toukokuussa heinässä oli sulavaa raakavalkuaista (srv) $92 \mathrm{~g}$ ja kaurassa $95 \mathrm{~g}$ rehuyksikköä kohden ja syyskuussa 95 ja $114 \mathrm{~g}$ vastaavasti. Heinien täyttävyys oli keskim. 1.82 ja 1.91 vastaavasti. Syyskuun heinissä oli enemmän tuhkaa ja useimpia kivennäis- ja hivenaineita kuin toukokuun heinissä, kun taas kauroissa oli rautaa lukuunottamatta kivennäis- sekä hivenaineita vastaavasti vähemmän (Taulukko 1).

Rehunkulutus ja energian ja sulavan raakavalkuaisen s a a n t i. Ruokinnan koostuessa pääasiassa heinistä ja kauroista koe-eläimet söivät Ija II-koejaksojen aikana päivässä keskim. 6.8 ja $7.1 \mathrm{~kg}$ heiniä sekä 3.8 ja $4.3 \mathrm{~kg}$ kauroja vastaavasti. Ne saivat heinistä keskim. 3.49 ja 3.27 ry ja 320 ja 330 g srv ja väkirehusta keskim. 3.41 ja 3.27 ry ja 324 ja 372 g srv päivässä. Toisin sanoen, hevoset ovat saaneet heinistä ja väkirehusta keskimäärin lähes yhtä suuret määrät rehuyksiköitä ja sulavaa raakavalkuaista päivittäin. Eri hevosilla ilmeni kuitenkin melko suuria yksilöllisiä eroja tässä suhteessa. Heinien suhteellinen osuus rehuannoksessa ry- ja srv-lähteenä vaihteli 
Taulukko 2. Eri ratsujen keskim. päivässä syömät ka-, srv- ja ry-määrät touko- (I) ja syyskuussa (II) sekä päivittäinen työntuntimäärä koejaksojen aikana.

Table 2. Mean daily intakes of dry matter, digestible crude protein and feed units and the work hours in May $(I)$ and September (II) of each saddle horse.

\begin{tabular}{|c|c|c|c|c|c|c|c|c|c|c|c|c|c|c|}
\hline \multirow[t]{2}{*}{$\begin{array}{l}\text { Hevonen } \\
\text { Horse }\end{array}$} & \multirow{2}{*}{\multicolumn{2}{|c|}{$\begin{array}{c}\text { Ikä v. } \\
\text { Age } \\
\text { years }\end{array}$}} & \multirow[t]{2}{*}{$\begin{array}{l}\text { Elop. } \\
\text { live } \\
\text { wt. } \mathrm{kg}\end{array}$} & \multirow[t]{2}{*}{$\begin{array}{l}\text { Säkä- } \\
\text { kork. } \\
\text { wither } \\
h t . \mathrm{cm}\end{array}$} & \multicolumn{5}{|c|}{$\begin{array}{c}\text { Syönyt yhteensä päivässä } \\
\text { Total daily intake }\end{array}$} & DCP & \multicolumn{2}{|c|}{$\begin{array}{l}\text { Heinistä } \\
\quad \% \text { ry } \\
\text { From hay } \\
\% \text { FU }\end{array}$} & \multicolumn{2}{|c|}{$\begin{array}{c}\text { Työtunt. } \\
\text { päivässä } \\
\text { work, } \\
\text { hr/day }\end{array}$} \\
\hline & & & & & I & II & I & II & I & II & I & II & I & II \\
\hline Almi & $\mathbf{r}$ & 8 & 325 & 124 & 4.68 & - & 2.84 & - & 263 & - & 81 & - & $\mathbf{S}$ & - \\
\hline 0 Solar Lady & $t$ & 6 & 445 & 160 & 9.55 & 9.41 & $6.92 *$ & 6.33 & 655 & 675 & 51 & 49 & 1.00 & 01.00 \\
\hline Paukku & $\mathbf{r}$ & 8 & 455 & 153 & 10.10 & 9.94 & 7.52 & 6.45 & 698 & 730 & 43 & 46 & 2.50 & 02.95 \\
\hline 0 Liekki & $\mathbf{r}$ & 22 & 480 & 162 & 8.06 & 7.99 & $6.02 *$ & 5.39 & 580 & 582 & 43 & 45 & 1.00 & 1.00 \\
\hline Nigger & $\mathrm{t}$ & 8 & 500 & 152 & 8.44 & 8.16 & 5.64 & 5.08 & 525 & 537 & 62 & 62 & 2.25 & 52.84 \\
\hline Baboll & $\mathbf{r}$ & 7 & 505 & 163 & 8.67 & 8.97 & 6.73 & 6.24 & 632 & 678 & 36 & 39 & 2.50 & 2.63 \\
\hline Rondo & $\mathbf{r}$ & 4 & 510 & 157 & 9.68 & 9.40 & 6.81 & 6.10 & 636 & 652 & 52 & 53 & 1.25 & 51.68 \\
\hline Hawest & $\mathbf{r}$ & 12 & 520 & 151 & 10.36 & 10.26 & 7.43 & 6.75 & 695 & 724 & 49 & 50 & 2.25 & 52.79 \\
\hline Silva** & $\mathrm{t}$ & 9 & 525 & 163 & 9.98 & 9.83 & 7.22 & 6.50 & 675 & 698 & 48 & 49 & 1.00 & 1.00 \\
\hline Jeanette & $t$ & 8 & 535 & 154 & 8.60 & 8.33 & 5.73 & 5.17 & 533 & 546 & 62 & 63 & 2.00 & 2.79 \\
\hline Nape & $\mathbf{r}$ & 12 & 545 & 158 & 10.20 & 9.84 & 7.34 & 6. & 687 & 702 & 49 & 49 & 2.25 & 52.63 \\
\hline Honey & $t$ & 7 & 550 & 158 & 9.10 & 8.92 & 6.25 & 5.68 & 583 & 604 & 57 & 57 & 2.00 & 2.81 \\
\hline Hazard & $\mathbf{r}$ & 6 & 552 & 161 & 11.06 & 10.82 & 8.06 & 7.22 & 754 & 777 & 47 & 47 & 2.50 & 3.21 \\
\hline 0 Puma & $\mathbf{r}$ & 7 & 557 & 164 & - & 9.47 & - & 6.16 & - & 659 & - & - 53 & - & $-s$ \\
\hline 0 Martini & $\mathrm{r}$ & 6 & 560 & 163 & 9.46 & - & $6.98^{*}$ & - & 661 & - & 46 & - & 1.00 & - \\
\hline Ton & $\mathrm{t}$ & 8 & & 163 & 9.14 & 8.89 & 6.27 & 5.66 & 585 & 60 & 57 & 57 & 2.67 & 72.26 \\
\hline Monty & $\mathbf{r}$ & 12 & 580 & 164 & 11.22 & 10.98 & 8.15 & 7.32 & 762 & 788 & 47 & 47 & 2.00 & 2.58 \\
\hline 0 Lock & $\mathbf{r}$ & 12 & 590 & 167 & 9.27 & 9.78 & $7.62 *$ & $7.25 *$ & 732 & 791 & 30 & 32 & 1.00 & 1.50 \\
\hline 0 Katja & $\mathrm{t}$ & 11 & 590 & 170 & 8.49 & - & 5.64 & - & 525 & - & 63 & - & S & - \\
\hline Titan & $\mathbf{r}$ & 6 & 600 & 164 & 11.18 & 10.86 & 8.12 & 7.24 & 760 & 779 & 47 & 48 & 1.50 & 1.58 \\
\hline 0 Nor & $\mathrm{r}$ & 1 & & 10 & 10.65 & 10.67 & 1.70 & 7.0 & 696 & $7:$ & 55 & 50 & 1.00 & 1.00 \\
\hline Tarz & $\mathbf{r}$ & 11 & & 158 & 9.60 & 9.27 & 6.53 & 5.86 & 609 & 622 & 59 & 59 & 2.25 & 2.84 \\
\hline Skipper & $\mathbf{r}$ & 7 & & 16 & 10.95 & 10.61 & 7.51 & 6.74 & 701 & 717 & 57 & 58 & 1.20 & 1.84 \\
\hline 0 Valeur & $\mathbf{r}$ & 8 & & 173 & 12.47 & 13.11 & 9.06 & 8.88 & 846 & 959 & 45 & 44 & 1.00 & 1.00 \\
\hline Comet & 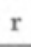 & 11 & 662 & 172 & 14.19 & 14.57 & 10.33 & 9.60 & 968 & 1035 & 45 & 46 & 2.50 & 2.58 \\
\hline
\end{tabular}

$\mathrm{r}=$ ruuna, gelding; $\mathrm{t}=$ tamma, mare; ${ }^{* *}=$ täysveri, thoroughbred; $0=$ yksityishevonen, privately owned; $\mathrm{S}=$ seisoi, idle; ${ }^{*}=$ saanut lisärehuja, received supplements; $D M=$ dry matter; $F U=$ feed units; $D C P=$ digestible crude protein.

säännöllisesti ratsastetuilla hevosilla $30-60 \%$ :n ja joutilailla ratsuilla $53-81 \%$ :n välillä (Taulukko 2). Päivässä syöty ka-määrä vaihteli eri hevosilla I-kokeessa $8.01-14.19$ $\mathrm{kg}$ :n (keskim. $9.78 \mathrm{~kg}$ ) ja II-kokeessa 7.99—14.57 kg:n (keskim. $10.0 \mathrm{~kg}$ ) välillä. Poni söi kuiva-ainetta vain $4.68 \mathrm{~kg}$ päivässä. Kookkaat hevoset pystyivät syömään enemmän kuin pienet (Taulukko 2). Heinien osuus koko kuiva-ainemäärästä oli I-kokeessa keskimäärin $62 \%$ ja II-kokeessa $65 \%$. 
Taulukko 3. Hevosten keskim. päivässä heinistä + kauroista saamat kivennäis- ja hivenainemäärät ja heinien suhteellinen osuus kivennäis- ja hivenaineiden lähteenä.

Table 3. Average amounts of minerals and trace elements obtained from hay + oats daily per horse and the relative amounts supplied by hay only

\begin{tabular}{|c|c|c|c|c|}
\hline \multirow[b]{2}{*}{$\begin{array}{l}\text { Alkuaine } \\
\text { Element }\end{array}$} & \multicolumn{2}{|c|}{$\begin{array}{l}\text { Toukokuussa } \\
\text { In May (I) }\end{array}$} & \multicolumn{2}{|c|}{$\begin{array}{c}\text { Syyskuussa } \\
\text { In September (II) }\end{array}$} \\
\hline & $\begin{array}{c}\text { Saatu keskim. } \\
\text { päivässä } \\
\text { Total intake } \\
\text { per day }\end{array}$ & $\begin{array}{c}\text { Heinien } \\
\text { osuus \% } \\
\text { Obtained } \\
\text { from hay } \%\end{array}$ & $\begin{array}{c}\text { Saatu keskim. } \\
\text { päivässä } \\
\text { Total intake } \\
\text { per day }\end{array}$ & $\begin{array}{c}\text { Heinien } \\
\text { osuus \% } \\
\text { Obtained } \\
\text { from hay } \%\end{array}$ \\
\hline $\mathrm{Ca} \mathrm{g}$ & 23.6 & 71.4 & 34.4 & 90.0 \\
\hline $\mathrm{Mg}$, & 11.9 & 62.2 & 13.0 & 63.0 \\
\hline $\mathbf{P} \quad$, & 23.8 & 44.5 & 25.0 & 46.7 \\
\hline $\mathbf{K} \quad$ & 99.5 & 85.0 & 113.0 & 94.0 \\
\hline $\mathrm{Na}$, & 9.8 & 80.5 & 22.5 & 88.0 \\
\hline $\mathrm{Fe} \quad \mathrm{mg}$ & 695 & 57.6 & 1592 & 52.3 \\
\hline $\mathrm{Cu}$, & 357 & 66.0 & 201 & 72.0 \\
\hline $\mathrm{Zn}_{\mathrm{n}}$, & 492 & 55.0 & 348 & 53.6 \\
\hline Mn , & 355 & 48.6 & 388 & 49.8 \\
\hline $\mathrm{Ca}: \mathrm{P}$ & 0.99 & - & 1.39 & - \\
\hline
\end{tabular}

Eri hevosten kohdalla heinien suhteellinen osuus rehuannoksessa ei näyttänyt riippuvan työtuntien määrästä eikä hevosten koostakaan (Taulukko 2). Päivittäinen ry-kulutus 100 elopainokiloa kohden oli I-kokeessa keskimäärin 1.28 ja II-kokeessa 1.20. Toisaalta hevosten työtuntimäärä oli II-kokeessa jonkin verran korkeampi kuin I-kokeessa. Jos joutilaina olleita eläimiä ei oteta huomioon, päivittäinen ry-kulutus/100 kg elop. korreloitui varsin heikosti hevosten keskimääräiseen työtuntimäärään. Esim. II-kokeen aikana $1-1.5 \mathrm{t} / \mathrm{pv}$ työskennelleillä hevosilla ry-kulutus/100 kg elop. vaihteli $1.12-1.42$ ry:n välillä päivässä, kun taas yli 2.5 t/pv työskennelleillä se vaihteli $0.95-1.45$ ry:n välillä.

Kivennäis- ja hivenaineiden saanti heinistä ja ka uroista. Taulukossa 3 on annettu keskim. hevosta kohden päivässä heinistä + kauroista yhteensä saadut kivennäis- ja hivenainemäärät sekä heinien suhteellinen osuus kivennäis- ja hivenaineiden lähteenä I-II-kokeiden aikana.

Kalsiumin päivittäinen saanti vaihteli eri hevosilla I-kokeessa $18.3-33.0 \mathrm{~g}$ :n ja fosforin saanti 18.8 - 36.0 g:n välillä ja II-kokeessa 25.9-47.1 g:n ja 19.1-37.0 g:n välillä vastaavasti. I-kokeessa ponilla Ca:n saanti oli 13.2 ja P:n saanti $9.0 \mathrm{~g}$. Suhteen $\mathrm{Ca} / \mathrm{P}$ vaihtelurajat olivat hevosilla I-kokeessa $0.77-1.18$ (ponilla 1.47) ja II-kokeessa 1.06-1.69. Rehuannoksen heinä-kaura suhde vaikutti erityisesti Ca:n saantiin, mikä oli alhaisin runsaasti väkirehua syöneillä hevosilla. Päivittäin syöty ka-määrä ei sanottavasti vaikuttanut rehuannoksen $\mathrm{Ca} / \mathrm{P}$-suhteeseen.

Magnesiumin päivittäinen saanti vaihteli hevosilla I-kokeessa 9.7-17.3 g:n (ponin 5.6 g) ja II-kokeessa 10.4-18.6 g:n välillä. Heinä-kaura suhde ei sanottavasti vaikuttanut $\mathrm{Mg}$ :n saantiin, vaan saanti lisääntyi lähinnä rehun kokonaiskulutuksen noustessa. 
Kaliumin saanti hevosta kohden päivässä vaihteli I-kokeessa 75-138 g:n (poni $58 \mathrm{~g}$ ) ja II-kokeessa 86-154 g:n välillä. Heinien osuus K:n lähteenä oli 85 ja $94 \%$ vastaavasti (Taulukko 3).

Natriumia hevoset saivat päivittäin 7.7-13.8 g (poni $5.5 \mathrm{~g}$ ) I-kokeessa ja 17.3 -31.2 g II-kokeessa. I-kokeessa keskimäärin päivässä saatu Na-määrä, $9.8 \mathrm{~g}$, vastaa $24.6 \mathrm{~g}: \mathrm{n}$ ruokasuolamäärää $(\mathrm{NaCl})$ ja II-kokeessa keskimäärin päivässä saatu Na-määrä, $22.5 \mathrm{~g}$, vastaa $56.5 \mathrm{~g}: \mathrm{n} \mathrm{NaCl}$-määrää. Pääosan natriumista hevoset saivat heinistään (I-kokeessa $80.5 \%$ ja II-kokeessa $88 \%$ ).

Raudan saanti vaihteli I-kokeen hevosilla 576-1025 mg:n (poni $310 \mathrm{mg}$ ) ja IIkokeen hevosilla $1256-2323 \mathrm{mg}: \mathrm{n}$ välillä. Heinä-kaura suhde vaikutti raudan saantiin vähemmän kuin päivittäin syöty kuiva-ainemäärä.

Kuparia hevoset ovat kummassakin kokeessa saaneet jonkin verran enemmän heinistä kuin kauroista (Taulukko 3). I-kokeessa Cu:n päivittäinen saanti vaihteli eri hevosilla 307-443 mg:n (poni $173 \mathrm{mg}$ ) ja II-kokeessa 159-285 mg:n välillä.

Sinkin päivittäinen saanti vaihteli I-kokeen eri hevosilla 413-735 mg:n (poni 215 mg) ja II-kokeen hevosilla 275-507 mg:n välillä. Heinä-kaura suhde ei sanottavasti vaikuttanut $\mathrm{Zn}$ :n saantiin, vaan saanti riippui lähinnä syödystä kuiva-ainemäärästä.

Mangaania hevoset saivat I-kokeessa keskimäärin $355 \mathrm{mg}$ ja II-kokeessa $388 \mathrm{mg}$ päivässä saannin vaihdellessa eri hevosilla $287-533 \mathrm{mg}: \mathrm{n}$ (poni $142 \mathrm{mg}$ ) ja $302-571$ mg:n välillä vastaavasti. Heinä-kaura suhde ei sanottavasti vaikuttanut $\mathrm{Mn}: \mathrm{n}$ saantiin, vaan saanti riippui lähinnä päivittäin syödystä kuiva-ainemäärästä.

\section{Tulosten tarkastelu}

Hevosen ravinnontarpeesta esiintyy kirjallisuudessa hyvin kirjavia ja puutteellisia tietoja (ref. Olsson ja Ruudvere 1965, Olsson 1969). Suurin osa ravinnontarvetutkimuksista on sitäpaitsi suoritettu työhevosilla, joilla saatuja tuloksia on vaikea rinnastaa lämminverirotujen ravinnontapeeseen ainakin niiltä osin mitä tulee työn aiheuttamaan tarpeeseen. Kiinnostus urheiluhevosten ravitsemusta kohtaan on kuitenkin lisääntynyt selvästi viime aikoina.

Energian ja srv:n tarve ja saanti. Seuraavassa yhdistelmässä on annettu LARssovin et al. (1951) suosittelemat ry-määrät ylläpitoa ja työsuoritusta varten päivässä. Srv-tarve on yhdistelmään laskettu edellyttämällä, että hevonen tarvitsee ylläpitoon ja työsuoritukseen tarvitsemassaan rehuannoksessa $80 \mathrm{~g}$ srv/ry (ref. Olsson ja RUUDVERE 1965):

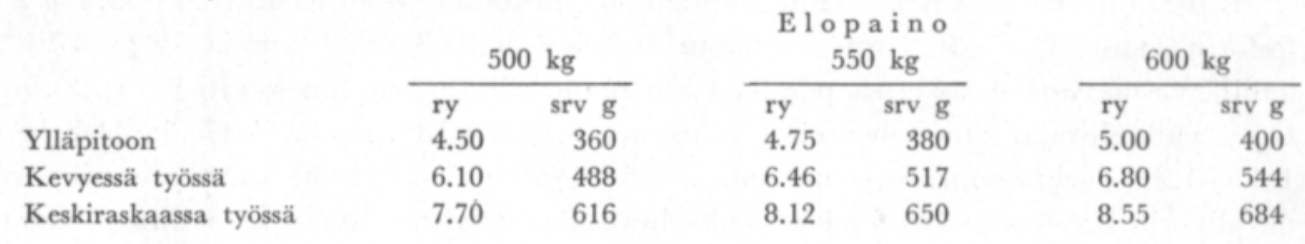

Hanssonin (1938) sekä ry- että srv-normit ovat edellä annettuja arvoja jonkin verran korkeammat. PALOHEIMon (1956) mukaan sulavaa raakavalkuaista tulisi antaa $90-100$ g/ry. JESPERSENin (1941) mukaan työn aiheuttama energian tarve on erittäin kevyessä 
työssä 0.2 , kevyessä 0.3 , keskiraskaassa 0.5 , raskaassa 0.7 ja erittäin raskaassa työssä 1.0 ry tunnissa.

Hevosten energian tarve voidaan myös ilmaista käyttämällä esim. sulavaa energiaa (DE) energiayksikkönä. N.R.C:n (1966) mukaan hevosten ylläpitoon päivässä tarvitsema DE-määrä voidaan laskea kaavasta: $\mathrm{DE} \mathrm{kcal}=138.3 \mathrm{~W}^{\mathbf{0 . 7 5}} \mathrm{kg}$. Lämminverihevosten ylläpitotarve oli Woodenin et al. (1970) tutkimuksessa: DE kcal $=142.2 \mathrm{~W}^{0.75} \mathrm{~kg}$. HrNTzin et al. (1971) suorittamien tutkimusten mukaan urheiluhevoset tarvitsevat ylläpitoenergian lisäksi kevyessä työssä (hidasta ravia ja hiukan laukkaa) $5.1 \mathrm{kcal} \mathrm{DE} / \mathrm{t}$ elopainokiloa kohti, keskiraskaassa (nopeata ravia, laukkaa, jonkinverran esteiden hyppäämistä) 12.1 kcal, raskaassa (harjoitus- ja kenttälaukkaa, esteiden hyppäämistä) 24.0 kcal ja erittäin raskaassa työssä (esim. poolopelin aikana) 39.0 kcal vastaavasti. PALOHEIMon (1956) mukaan yhden ry:n työtuotantovaikutus hevosella on $870 \mathrm{kcal}$. nettoenergiaa.

Tässä tutkimuksessa hevosten keskim. elopaino oli n. $550 \mathrm{~kg}$; hevoset söivät I-koejakson aikana keskimäärin 7.18 ja II-koejakson aikana 6.6 ry päivässä. Kokeissa oli mukana 2 joutilasta hevosta ja yksi poni (Taulukko 2). Muita 22 tutkimuksessa ollutta hevosta käytettiin säännöllisesti ratsastukseen. Kun näille laskettiin kummankin koejakson ajalta keskim. päivässä saatu ry-määrä ja keskim. päivittäinen työtuntimäärä, saatiin päivittäiseksi ry-kulutukseksi keskimäärin 6.95 ja työajaksi 1.91 tuntia. Kun ko. hevosten ylläpitoravinnontarve laskettiin LARssonin et al. (1951) suositusnormien mukaan, saatiin päivittäiseksi ylläpitotarpeeksi keskimäärin 4.77 ry (vaihtelurajat $4.2-5.3$ ry). Vähennettäessä kokonais ry-kulutuksesta ylläpitoon tarvittu ry-määrä saatiin ns. työhön kulutettu ry-määrä (keskim. $2.19 \mathrm{ry} / \mathrm{pv}$ ). Tämä jaettiin työtuntien määrällä, jolloin saatiin ry-kulutus työtunnissa (keskim. 1.38), mikä vaihteli eri hevosilla 0.34 3.74 ry:n välillä. Jos laskelman perusteella saatua keskimääräistä ry-kulutusta, 1.38 ry/työtunti, verrataan JESPERSENin (1941) antamiin normeihin, on tämän tutkimuksen hevosten työ ollut keskim. erittäin raskasta.

Tässä tutkimuksessa tammojen keskim. ry-kulutus (0.99 ry/työtunti) oli pienempi kuin ruunien $(1.54 \mathrm{ry} / \mathrm{t}$ ) ja tuntihevosten (1.01 ry/t) pienempi kuin yksityishevosten (2.39 ry/t). LARssonin et al. (1951) mukaan kevyt työ vaatii 1.6 ja normaali työ 3.2 ry/pv. LARssonin et al. normeihin verrattuna voidaan tässä tutkimuksessa mukana olleiden 22 hevosen työ ry-kulutuksen (I+II koeajaksojen keskiarvo $2.19 \mathrm{ry} / \mathrm{pv}$ ) perusteella luokitella kevyen ja normaalin työn välimaille.

Hintz et al. (1971) tutkiessaan ratsuhevosten energian kulutusta laskivat ylläpitoon tarvittavan DE-määrän kaavalla: DE kcal $=155 \mathrm{~W}^{0.75} \mathrm{~kg}$. Hevosten saamat heinät sisälsivät $2.11 \mathrm{Mcal} \mathrm{DE} / \mathrm{kg}$ ja kaurojen oletettiin sisältävän $2.73 \mathrm{Mcal} \mathrm{DE} / \mathrm{kg}$. Tutkimuksessa oli mukana 9 pooloponia, jotka saivat myös rehupellettejä sekä 7 ns. tuntihevosta. Pooloponien todettiin kuluttavan intensiivisen pelin aikana keskim. 31.7 ja tuntihevosten $9.3 \mathrm{kcal} \mathrm{DE} / \mathrm{t} / \mathrm{kg}$. HrNTzin et al. laskuperusteita soveltaen tämän tutkimuksen 22:lle säännöllisesti ratsastetulle hevoselle keskimääräiseksi työhön kulutetun energian määräksi saatiin I-koejakson aikana 12.55 (5.19-27.43) ja II-koejakson aikana 11.91 kcal DE/ t/kg (4.28-28.07). Tutkimuksen 6 tammaa kulutti keskim. 11.6 ja 9.7 sekä 16 ruunaa $12.9 \mathrm{ja} 12.7 \mathrm{kcal} \mathrm{DE} / \mathrm{t} / \mathrm{kg}$ vastaavasti. Kuusi intensiivisesti noin tunnin ajan päivittäin ratsastettua yksityishevosta kulutti I-koejakson aikana keskimäärin 19.2 ja II-koejakson aikana $20.5 \mathrm{kcal} \mathrm{DE} / \mathrm{t} / \mathrm{kg}$, kun taas $16: \mathrm{n}$ tuntihevosen keskim. energian kulutus oli vain 
10.0 ja $8.7 \mathrm{kcal} \mathrm{DE} / \mathrm{t} / \mathrm{kg}$ vastaavasti. Hinzin et al. esittämään aktiviteettiasteikkoon verrattuna yksityishevosten työ on ollut keskiraskasta — raskasta mutta tuntihevosten työ kevyttä — keskiraskasta.

Kuten edellä esitetystä on käynyt ilmi, energian kulutus työtuntia kohden vaihteli melkoisesti eri hevosilla. Kaikkia energian hyväksikäyttöön vaikuttavia tekijöitä ei ole kuitenkaan voitu kokeita suoritettaessa ottaa huomioon. Ratsuhevosilla energian tarve työtuntia kohden riippuu paitsi hevosen koosta myös ratsastajan painosta, kelin raskaudesta, harjoituksen laadusta (esteet, maasto, kenttä) ja intensiivisyydestä, hevosen temperamentista, fyysisestä kunnosta ja koulutusasteesta. Flegmaattinen hevonen kokemattoman ratsastajan ratsastamana kuluttaa vähemmän rehuyksiköitä työtuntia kohdenkuin kokeneen ratsastajan ratsastama temperamenttinen hevonen intensiivisessä kilpailu treenauksessa. Hevosilla esiintyy ilmeisesti myös eroja rehun hyväksikäytössä, mikä saattaa esim. johtua hampaiden kunnosta, rehun sulatuksen tehokkuudesta ruoansulatuskanavassa, ravinnon energia - proteiinisuhteesta tai muista ruokintatekijöistä ja loisista. Sukupuolellakin saattaa olla merkitystä, koska tässä tutkimuksessa tammat kuluttivat keskim. vähemmän energiaa kuin ruunat.

Sulavan raakavalkuaisen saanti oli I-kokeen aikana pienempi kuin II-kokeen aikana. Kummankin kokeen aikana rehuissa oli sulavaa rakavalkuaista niin paljon (heinissä 92 ja $101 \mathrm{~g}$ :/ry kauroissa 95 ja $114 \mathrm{~g} / \mathrm{ry}$, Taulukko 1), että hevosten srv-tarve on tullut tyydytetyksi jopa PALOHErmon (1956) suhteellisen korkeiden normilukujen (90-100 g srv/ry) perusteella. Kuitenkin toisaalta kilpailutreenauksessa oleville lämminverihevosille suositellaan vieläkin korkeampia srv-määriä (ref. BorgmanN 1972).

K ivennä is- ja hive na in eide n t a rve ja s a a t i. Breiremin (1938) mukaan $500 \mathrm{~kg}$ painava hevonen tarvitsee kalsiumia $12-15 \mathrm{~g} / \mathrm{pv}$ sekä samanverran fosforia, ja Ca/P ei saisi olla alle 0.7. Axelsson (1943) taas suosittelee 30-40 g kalsiumia ja 21-29 g fosforia täysikasvuiselle hevoselle päivässä. Hänen käsityksensä mukaan nuorella hevosella Ca/P-suhteen tulisi olla 1.5-1.7. Schryver ja Hrntzin (1972) mukaan ylläpitorehussa tulisi olla $0.35 \%$ kalsiumia ja $0.25 \%$ fosforia $(3.5 \mathrm{ja} 2.5 \mathrm{~g} / \mathrm{kg})$. Heidän käsityksensä mukaan $\mathrm{Ca} / \mathrm{P}$ voi vaihdella $1.4-2.0 / 1$ edellyttäen, että rehuannoksessa on riittävästi molempia kivennäisiä. Liiallinen $\mathrm{P}$ on haitallista, se johtaa nutritionaaliseen sekundääriseen hyperparatyroidismiin (NSH) ja tämän kautta luustovaurioihin. Liiallinen P sitäpaitsi ehkäisee Ca:n ja myös Mg:n hyväksikäyttöä (HrNTz ja Schryver 1972). Runsas Ca-määrä, $2 \%$ rehuannoksessa, alentaa myös $\mathrm{Mg}: \mathrm{n}$ ja lisäksi $\mathrm{Mn}: \mathrm{n}$ ja Fe:n hyväksikäyttöä (WHrtLock et al. 1970) mutta ei näytä vaikuttavan Zn:n hyväksikäyttöön (O'NeILl et al. 1971, unpublished observations).

Tässä tutkimuksessa hevoset saivat I-kokeessa kalsiumia keskimäärin 23.6 ja fosforia 23.8 g päivässä, mitkä määrät ovat olleet BreIremin (1938) ja Axelssovin (1943) suositusten välimailta. II-kokeessa Ca:n $(34.4 \mathrm{~g} / \mathrm{pv})$ ja P:n $(25.0 \mathrm{~g} / \mathrm{pv})$ määrät ovat yltäneet suunnilleen Schryverin ja Hrntzin (1972) normeihin; hevosten keskimääräinen päivittäinen ka-kulutus oli noin $10 \mathrm{~kg}$ (Taulukko 2). Ca/P oli I-kokeessa keskimäärin 0.99 ja II-kokeessa 1.39 (Taulukko 3). I-kokeen aikana ainakin Ca-lisäys olisi ollut paikallaan. HARveyn et al. (1943) mukaan työ ei sanottavasti lisää Ca:n ja P:n tarvetta työhevosilla. Schryverin ja Hintzin (1972) mukaan työn aiheuttamaa tarvetta ei tarkoin tunneta, mutta täysikasvuiselle hevoselle riittänee $0,4 \%$ kalsiumia ja $0.3 \%$ fosforia rehuannoksessa. Tässä tutkimuksessa Ca:n ja P:n saanti on jäänyt mainittuja määriä vähäisemmäksi. 
Heinien osuus koehevosten Ca-lähteenä oli I-kokeessa 71 ja II-kokeessa $90 \%$ (Taulukko 3), ja heinät sisälsivät kalsiumia keskimäärin noin $3 \mathrm{ja} 5 \mathrm{~g} / \mathrm{kg}$ ka (Taulukko 1). LAKASEN (1969) mukaan timoteiheinien Ca-pitoisuus on alhaisempi Suomen pohjois- kuin eteläosissa, kun taas P-pitoisuus on samaa suuruusluokkaa vastaavasti. Mainitun havainnon perusteella ainakin Ca-lisäys hevosten rehuannokseen varsinkin maamme pohjoisimmilla alueilla on paikallaan.

Hevosen magnesiumtarve on noin 13-14 mg elopainokiloa kohden (HrNTz \& Schryver 1972) eli $550 \mathrm{~kg}$ painavalla hevosella noin $7.5 \mathrm{~g} / \mathrm{pv}$. Tähän tarvelukuun verrattuna hevoset ovat saaneet kummankin koejakson aikana riittävästi magnesiumia.

Kaliumin tarvetta ei hevosella tunneta tarkoin, mutta saannin sanotaan olevan turvatun jos rehuannos sisältää korsirehua $50 \%$ (N.R.C. 1966). Tässä tutkimuksessa hevoset söivät keskimäärin noin $7 \mathrm{~kg}$ heinää ja noin $4 \mathrm{~kg}$ kauroja päivässä. Kaliumia ne ovat saaneet noin $20 \mathrm{~g} / 100 \mathrm{~kg}$ elop.

LARsson et al. (1951) suosittelevat täysikasvuisille kevyille siitoshevosille NaCl:n tarpeeksi $30-50 \mathrm{~g} / \mathrm{pv}$. DrepPer (1972) suosittelee urheiluhevosten päivittäiseksi NaCl:n tarpeeksi $5 \mathrm{~g} / 100 \mathrm{~kg}$ elop. minkä mukaan $550 \mathrm{~kg}$ painavat hevoset tarvitsevat yhteensä $27.5 \mathrm{~g} \mathrm{NaCl} / \mathrm{pv}$. Tässä tutkimuksessa hevoset saivat I-koejakson aikana natriumia keskimäärin $9.83 \mathrm{~g}$ ja II-koejakson aikana $22.5 \mathrm{~g} / \mathrm{pv}$. Nämä Na-määrät vastaavat $24.6 \mathrm{ja}$ $56.5 \mathrm{~g} \mathrm{NaCl}$. I-kokeessa $\mathrm{NaCl}: \mathrm{n}$ saanti on ollut niukkaa mutta II-kokeessa runsasta verrattuna em. suosituksiin. Heinien osuus Na-lähteenä oli $80.5-88.0 \%$ (Taulukko 3). Mainittakoon, että eri heinänäytteissä Na-pitoisuus vaihteli melkoisesti, joten yksi heinänäyte ei riitä Na:n saannin arvioimiseksi. Kun koehevosille tarjottiin keväällä natriumkloridia suolakiven muodossa, lähes puolet hevosista nuoli kiveä halukkaasti. NaCl:n tarve lisääntyy työmäärän suurentuessa, koska sitä poistuu hien mukana elimistöstä.

Hevosten raudan tarvetta ei tunneta tarkoin. Olssovin (1969, s. 939) mukaan 80 ppm ja N.R.C:n (1966) mukaan 40 ppm rautaa rehussa on riittävä määrä. DrePPER (1972) suosittelee urheiluhevosille annettavaksi päivittäin $100 \mathrm{mg} \mathrm{Fe} / 100 \mathrm{~kg}$ elop. Tässä tutkimuksessa hevosten Fe-saanti oli I-koejakson aikana em. suositusten välimailta (n. 70 ppm tai noin $125 \mathrm{mg} / 100 \mathrm{~kg}$ elop.), kun taas II-koejakson aikana saanti ylitti selvästi em. suositusnormit. Kummassakin kokeessa kauroissa oli jonkin verran enemmän rautaa kuin heinissä. Koska hevoset kuitenkin söivät keskimäärin enemmän heinän kuin kauran kuiva-ainetta, niin heinistä saatu Fe-määrä ylitti kaurasta saadun Fe-määrän.

Osssonin (1969) mukaan 5-8 mg kuparia/kg ka riittää peittämään hevosen Cutarpeen. Drepper (1972) suosittelee urheiluhevosille $10 \mathrm{mg} \mathrm{Cu} / 100 \mathrm{~kg}$ elop. Tässä tutkimuksessa heinien ja kaurojen Cu-pitoisuudet olivat varsinkin I-koejakson aikana korkeat (Taulukko 1), ja hevoset ovatkin saaneet em. suosituksiin verrattuna ylimäärin kuparia. Pohjois-Suomen alueilla timoteiheinän Cu-pitoisuus on alhainen, $3.1-5.9 \mathrm{ppm}$ (LAKANEN 1969), joten ko. olosuhteissa saattaa olla paikallaan antaa hevosille kuparia sisältävää kivennäissuolaseosta riittävän Cu-saannin turvaamiseksi.

DREPPER (1972) suosittelee urheiluhevosille sinkin tarpeeksi $40 \mathrm{mg}$ ja mangaanin tarpeeksi $20 \mathrm{mg} / 100 \mathrm{~kg}$ elop. eli $550 \mathrm{~kg}$ painavalle hevoselle $220 \mathrm{mg} \mathrm{Zn} \mathrm{ja} 110 \mathrm{mg} \mathrm{Mn}$ päivässä. Näihin määriin verrattuna koehevoset ovat saaneet riittävästi molempia hivenaineita (Taulukko 3). 


\section{Yhteenveto}

Toukokuussa (I) ja syyskuussa (II) suoritettiin rehunkulutus- ja ravinnonsaantitutkimuksia 24 ja 22 ratsulla vastaavasti. Hevosten keskipaino oli noin $550 \mathrm{~kg}$. Koe-eläimet söivät I- ja II-kokeen aikana keskimäärin päivässä 6.4 ja $7.1 \mathrm{~kg}$ heiniä sekä 3.8 ja 4.3 kg kauroja. Ne saivat heinistä keskimäärin 3.49 ja 3.20 ry sekä 320 ja 330 g srv ja väkirehusta 3.41 ja 3.27 ry sekä 324 ja 372 g srv vastaavasti. Hevoset söivät kuiva-ainetta keskimäärin noin $10 \mathrm{~kg}$ päivässä. Kulutus nousi hevosen koon lisääntyessä. Työhevosten normeihin verrattuna ratsuhevoset saivat riittävästi sulavaa raakavalkuaista heinistä ja kauroista.

22 säännöllisesti ratsastettua hevosta kulutti ylläpitoon LARssonin et al. (1951) normien mukaan laskettuna I+II koejaksojen aikana keskimäärin 4.77 ry päivässä ja työtuntia kohden keskimäärin 1.38 ry. Tammat kuluttivat keskimäärin 0.99 ja ruunat 1.54 ry työtunti. Tuntihevoset kuluttivat keskimäärin 1.01 ja yksityishevoset $2.39 \mathrm{ry} /$ työtunti. Mainitut 22 hevosta kuluttivat I- ja II-koejaksojen aikana Hintzin et al. (1971) laskuperusteiden mukaan sulavaa energiaa (DE) keskimäärin seuraavasti: tammat 11.6 ja 9.7 sekä ruunat $12.9 \mathrm{ja} 12.7 \mathrm{kcal} \mathrm{DE} / \mathrm{t} / \mathrm{kg}$; tuntihevoset 10.0 ja 8.7 sekä yksityishevoset $19.2 \mathrm{ja} 20.5 \mathrm{kcal} \mathrm{DE} / \mathrm{t} / \mathrm{kg}$ vastaavasti.

I- ja II-kokeissa kivennäis- ja hivenaineiden saanti hevosta kohden päivässä oli keskim.: Ca 23.6 ja 34.4 g, P 23.8 ja 25.0 g, Mg 11.9 ja 13.0 g, K 99.5 ja 113.0 g, Na 9.8 ja 22.5 g, Fe 695 ja 1592 mg, Cu 357 ja 201 mg, Zn 492 ja 348 mg, Mn 355 ja 388 mg ja $\mathrm{Ca} / \mathrm{P}$ oli 0.99 ja 1.39 vastaavasti.

Heinien osuus kivennäis- ja hivenaineiden lähteenä oli keskimäärin I- ja II-kokeissa: Ca 71 ja $90 \%$, P 44 ja $47 \%$, Mg 62 ja $63 \%$, K 85 ja $94 \%$, Na 81 ja $88 \%$, Fe 58 ja $52 \%$, Cu 66 ja $72 \%$, Zn 55 ja $54 \%$ sekä Mn 49 ja $50 \%$.

Kivennäis- ja hivenaineiden saanti oli normeihin verrattuna riittävää tai kohtalaisen runsasta lukuunottamatta kalsiumia, natriumia ja rautaa I-kokeen aikana.

\section{KIRJALLISUUS}

Axelsson, J. 1943. Hästarnas utfodring och skötsel. Nordisk Rotogravys, Stockholm.

Borgmann, F. 1972. Sportpferdefütterung heute. I \& II. Reiter Rev. 15:216-218, 346.

BREIREM, K. 1938. Vitaminer og mineralstoffer i husdjurens ernäering. Gronhdal \& Sons, Oslo.

DrepPer, K. 1972. Ernährungsphysiologie und Fütterung des Pferdes. Kraftf. 55:313 - 315.

Harvey, A. L., Thomas, B. H., Culbertson, C. C. \& Collins, E. V. 1943. Effect of work on the calcium and phosphorus retention of Percheron geldings. J. Anim. Sci. 2:103-111.

Hintz, H. F., Roberts, S. J., Sabin, S. W. \& Schryver, H. F. 1971. Energy requirements of light horses for various activities. J. Anim. Sci 32:100-102.

Hintz, H. F. \& Schryver, H. F. 1972. Magnesium metabolism in the horse. J. Anim. Sci. 35:755.

Jespersen, J. 1941. Maanedsskr. Dyrlaeger 53:409.

Lakanen, E. 1969. Mineral composition of Finnish timothy. Ann. Agric. Fenn. 8:20-29.

Larsson, S., Olsson, N., JArL, F. \& Olofsson, N. E. 1951. Husdjurslära. Vol. 2. L.T.:s Förlag, Stockholm.

N.R.C. 1966. Nutrient Requirements of Domestic animals. No. 6. Nutrient Requirements of Horses. National Research Council, Washington, D. C.

Otsson, N. O. 1969. The nutrition of the horse. In book: Nutrition of Animals of Agric. Importance. $2: 921-960$. 
Olsson, N. O. \& Ruudvere, A. 1965. The nutrition of the horse. Nutr. Abst. \& Revs. 25:1-8.

O'Neml, J., Walsh, J., Hintz, H. F. \& Schryver, H. F. 1971. Zinc utilization by ponies fed a high calcium diet (unpublished observations).

PALoheimo, L. 1956. Kotieläinhoidon perusteita. Jyväskylä.

Schryver, H. F. \& Hintz, H. F. 1972. Calcium and phosphorus requirements of the horse. A review. Feedstuffs July 10:35-38.

TAussky, H. H. \& SchorR, E. 1953. A microcolorimetric method for the determination of inorganic phosphorus. J. Biol. Chem. 202:675-685.

Whitrock, R. H., Hintz, H. T., Schryver, H. F., Krook, L. \& Craig, P. H. 1970. Effect of high calcium diets in horses. Proc. 2nd Equine. Nutr. Res. Symp. p. 12.

Wooden, G. R., Knox, K. L. \& Wird, C. L. 1970. Energy metabolism in light horses. J. Anim. Sci. $31: 544-548$. 